\title{
The Role of Prohepcidin and Hepcidin in Anemia Associated with Behçet's Disease
}

\author{
Mehmet DAGLI', Sema YILMAZ², Abdullah SIVRIKAYA ${ }^{3}$, Gulperi CELIK ${ }^{4}$ \\ ${ }^{1}$ Selcuk University, Selcuklu Faculty of Medicine, Department of Internal Medicine, Hematology Unit \\ ${ }^{2}$ Selcuk University, Selcuklu Faculty of Medicine, Department of Internal Medicine, Rheumatology Unit \\ ${ }^{3}$ Selcuk University, Selcuklu Faculty of Medicine, Department of Biochemistry \\ ${ }^{4}$ Selcuk University, Selcuklu Faculty of Medicine, Department of Internal Medicine, Nephrology Unit, Konya, TURKEY
}

\begin{abstract}
The aim of the study is to investigate the role of circulating prohepcidin and hepcidin, which are homeostatic regulators of iron metabolism and mediators of inflammation, in anemia associated with Behçet's disease (BD) and the differential diagnosis of healthy controls. Twenty patients with BD and twenty healthy controls were included in this prospective study. Laboratory tests including complete blood count, serum prohepcidin, hepcidin, iron, total iron binding capacity (TIBC), transferrin, ferritin, erythrocyte sedimentation rate (ESR) and C-reactive protein (CRP) were determined. Serum prohepcidin and hepcidin levels in patients with BD were significantly higher than healthy group. In the group with BD positive correlation was determined between the values of serum prohepcidin, hepcidin, hemoglobin, total binding capacity and ferritine. Serum prohepcidin and hepcidin levels are closely associated with disease activity in patients and might play a role in the pathobiology of chronic disease anemia associated with patients with BD.
\end{abstract}

Keywords: Prohepcidin, Hepcidin, Anemia, Behçet's disease

ÖZET

\section{Behçet Hastalığı ile iliş̧kili Anemide Prohepsidin ve Hepsidinin Rolü}

Çalışmamızın amacı; demir metabolizmasında homeostatik regülatör ve inflamasyon mediatörü olarak rol oynayan prohepsidin ve hepsidinin Behçet hastalığı (BH) ile ilişkili aneminin ayıııı tanısındaki önemini araştırmaktır. Yirmi Behçet hastası, 20 sağlıkI erişkin çalışmaya alındı. Hastalardan tam kan, serum prohepsidin ve hepsidin, demir, total demir bağlama kapasitesi (TIBC), transferin, ferritin, eritrosit sedimentasyon hızı (ESR), c-reaktif protein (CRP) düzeyleri ölçüldü. Serum prohepsidin ve hepsidin düzeyleri, behçet hastalı̆̆ $(\mathrm{BH})$ grubunda, sağlıklı kontrol (SK) grubuna göre önemli düzeyde yüksek bulundu. BH grubunda, serum prohepsidin ve hepsidin değerleri ile hemoglobin,demir bağlama kapasitesi, ferritin değerleri arasında korelasyon tespit edildi. Serum prohepsidin ve hepsidin seviyelerinin Behçet hastalığında, hastalık aktivitesiyle yakın ilişkisi saptanırken, oluşan kronik hastalık anemisinin patobiyolojisinde rol oynayabileceği düşünülmektedir.

Anahtar Kelimeler: Prohepsidin, Hepsidin, Anemi, Behçet hastalığı 


\section{INTRODUCTION}

Behçet's Disease is a multisystem inflammatory vasculitic syndrome of unknown etiology named after Hulusi Behçet, who described the clinical triad of aphthous ulcers, genital ulcers and iritis in 1937. ${ }^{1}$ It is now well-recognized that BD encompasses not only mucocutaneous, ocular, and vascular manifestations, but also musculoskeletal, neurologic, hematologic, pulmonary, gastrointestinal, and genitourinary manifestations. ${ }^{2}$

The anemia of chronic disease (ACD) is an acquired disorder occurring in patients with a variety of inflammatory disorders. ACD is thought to primarily reflect a reduction in red blood cell production by the bone marrow. ${ }^{3}$ Shortened erythrocyte lifespan, impaired erythropoietin (EPO) response, and impaired iron metabolism are suggested to be involved in the pathogenesis of ACD ${ }^{4}$ However, the molecular basis of ACD has not been fully elucidated. Cytokines, including IL-1, IL-6, TNF- $\alpha$, and interferons, are hypothesized to be involved in the maintenance of red blood cell production or stability. ${ }^{5,6}$

Hepcidin, a recently discovered anti-microbial, cysteine-rich cationic peptide hormone and its precursor prohepcidin, are the homeostatic regulators of intestinal iron absorption, iron recycling by macrophages and iron mobilization from hepatic stores. Hepcidin inhibits the cellular efflux of iron by binding to ferroportin and inducing the degradation of ferroportin..$^{-9}$ Hepcidin synthesis is increased by iron loading and decreased by anemia and hypoxia. Additionally, hepcidin synthesis is greatly induced during inflammation, trapping iron in macrophages, decreasing plasma iron concentrations, and causing anemia of inflammation..$^{10,11}$ Recent studies indicate that hepcidin, synthesized by the liver, known as type II acute-phase reactant, may play a key role in the pathogenesis of ACD and iron metabolism. ${ }^{12,13}$

In the present study, it was aimed to assess the role and significance of serum hepcidin, prohepcidin, in the development of ACD in patients with BD.

\section{PATIENTS AND METHODS}

Twenty patients with BD according to the International Study Group for BD criteria ${ }^{14}, 20$ age and sex-matched healthy controls were included in the study.

Detailed histories of all participants were obtained, and their systemic and rheumatologic examinations were carried out. Patients with other concomitant hematological diseases like sickle-cell anemia and thalassemia, heart, lung, kidney and liver diseases and acute or chronic infection, malignancy and current pregnancy or delivery within 6 months were excluded. Participants receiving blood transfusion, erythropoietin and iron treatment and with recent history of bleeding were also excluded. The local ethical committee of Selcuk University Selcuklu Medical Faculty approved the study protocol. Written informed consent was obtained from all participants.

Laboratory tests including complete blood count, serum prohepcidin, hepcidin, iron, total iron binding capacity (TIBD), transferrin, ferritin, ESR and CRP were analyzed. The blood samples were drawn from all participants who had fasted overnight. The blood samples without anticoagulant were centrifugated, and their serum was separated right after conceal. Serum transferrin, ferritin, iron, TIBC and CRP levels were immediately analyzed; however, serum samples were stored at $-85^{\circ} \mathrm{C}$ to analyze the levels of prohepcidin and hepcidin. The levels of serum transferrin were measured using Beckman Coulter test kits (lot No: T911130) iron, TIBC levels with Thermo test kits (lot No: V36305) in Synchron LX-20 auto-analyzer, and CRP levels with Siemens test kits (lot No:167504A) in Dade Behring auto-analyzer. Serum ferritin levels were measured in E170 auto-analyzer using Roche test kits (cat No: 03737551). Complete blood count was measured in Cell Dyn 4000 analyzer device using original kits (lot No:A0115), and ESR was analyzed through Alifax device. The analysis of prohepcidin (No: 12K069-3) and hepcidin (No: 39K119) were carried out in Kayto RT-2100 ELISA device by using DRG brand ELISA test kits.

The reference values were accepted as follows; $192-282 \mathrm{mg} / \mathrm{dl}$ for transferrin, $50-170 \mu \mathrm{g} / \mathrm{dl}$ for serum iron, $120-420 \mu \mathrm{g} / \mathrm{dl}$ for TIBC and 15-150 $\mathrm{ng} / \mathrm{ml}$ for ferritin. In order to exhibit the disease activity, the values of CRP and ESR were used. Serum CRP value of $>3.2$ and ESR value of $>20$ $\mathrm{mm} / \mathrm{h}$ were accepted as active values. 


\begin{tabular}{|c|c|c|c|}
\hline & BD $(n=20)$ & $C G(n=20)$ & p Values \\
\hline Age (year) & $36 \pm 11(18-60)$ & $33 \pm 12(19-65)$ & 0.645 \\
\hline $\mathrm{Hgb}$ (gr/dl) & $11 \pm 1.8(8-16)$ & $14.1 \pm 2.1(12-16)$ & 0.040 \\
\hline MCV (fl) & $84 \pm 5.2(71-90)$ & $88 \pm 9.1(80-94)$ & Not significant \\
\hline Iron ( $\mu \mathrm{g} / \mathrm{dl})$ & $86 \pm 54(36-101)$ & $89 \pm 15(20-173)$ & 0.477 \\
\hline TIBC ( $\mu \mathrm{g} / \mathrm{dl})$ & $232 \pm 46(120-34)$ & $278 \pm 21(178-401)$ & 0.296 \\
\hline Ferritin (ng/ml) & $61 \pm 50(6-201)$ & $45 \pm 7.1(15-97)$ & 0.018 \\
\hline Transferrin (mg/dl) & $268 \pm 47(191-366)$ & $183 \pm 26(146-243)$ & 0.018 \\
\hline CRP (mg/dl) & $19 \pm 10(5-47)$ & $3.1 \pm 2.7(1-6)$ & 0.001 \\
\hline Sedimentation (mm/hour) & $13 \pm 3.4(2-41)$ & $15 \pm 7.5(2-30)$ & 0.139 \\
\hline Prohepcidin (mg/dl) & $121 \pm 8.4(38-245)$ & $48 \pm 12(31-87)$ & 0.001 \\
\hline Hepcidin (mg/dl) & $45 \pm 12(26-67)$ & $66 \pm 28(11-176)$ & 0.001 \\
\hline
\end{tabular}

\section{Statistical Evaluation}

Statistical analysis was performed using the Statistical Package for the Social Sciences (SPSS, Version 18.0, Chicago, IL, USA). The results were expressed as mean $\pm \mathrm{SD}$. The comparisons between two groups were assessed using Mann-Whitney U test. The comparisons between two groups for Parametrics variables were performed using the independent-samples $\mathrm{T}$ test. Correlation analysis was performed using Pearson correlation tests.Multivariate analysis were performed with linear regression analysis. $\mathrm{P}$ values of $<0.05$ were considered to indicate statistical significance.

\section{RESULTS}

Data concerning to BD and control group have been shown in Table 1 . Mean age rate was higher in patients with $\mathrm{BD}$ (13 women, 7 men, mean age rate $36 \pm 10)$ compared to control groups $\mathrm{CG}(10$ women, 10 men,mean age rate $30 \pm 9$ ) . In literature, the incidence rate of $\mathrm{BD}$ is reported to be $2 / 1$ as $\mathrm{W} / \mathrm{M}$, and the rate is consistent with the one detected in the literature. The level of sedimentation was sicnificantly higher in BD group than level of control's. CRP levels were higher in BD group, compared to that control groups. In BD group, prohepcidin and hepcidin levels were significantly higher than healthy control groups. In BD group negative correla- tion between iron and TIBC $(\mathrm{r}=-0.571, \mathrm{p}=0.01)$, ferritin and TIBC $(r=0.477, p=0.03)$, hemoglobin and sedimentation $(\mathrm{r}=-0.498, \mathrm{p}=0.03)$, prohepcidin and ferritin $(\mathrm{r}=-0.542, \mathrm{p}=0.01)$ have been determined while correlations between ferritin and CRP $(r=$ $0.836, \mathrm{p}=0.01)$, sedimentation and CRP ( $\mathrm{r}=0.812$, $\mathrm{p}=0.01)$, CRP and ferritin $(\mathrm{r}=0.509, \mathrm{p}=0.02)$, hemoglobin and prohepcidin $(r=0.483, p=0.03)$ were positive. Prohepcidin and hepcidin levels in active BD group were observed to be significantly higher, compared to those in inactive BD group, and there was a significant association between them (Table2).

\section{DISCUSSION}

Behçet's Disease is a systemic inflammatory vasculitis syndrome characterized by a course of remissions and exacerbations of unpredictable frequency and duration. ${ }^{2}$ During the process of BD, ACD is frequently observed. ACD is normocytic normochromic anemia, with low levels of serum iron and transferrin, increased serum levels of ferritin, and a low reticulocyte response for the degree of anemia. ${ }^{15}$ IDA is hypochromic microcytic anemia is often confused with ACD. IDA is suggested by the finding of low serum ferritin levels, the absence of stainable iron on bone marrow aspiration / biopsy, or response to therapeutic of oral iron. ${ }^{16}$ 
Table 2. Percentage of anemia frequency in Active BD and Inactive BD groups, Values of Hgb, Prohepcidin and Hepcidin.

\begin{tabular}{|llll|}
\hline & Active BD $(\mathbf{n}=\mathbf{1 1})$ & Inactive $\mathbf{B D}(\mathbf{n}=\mathbf{9})$ & p values \\
\hline Anemia Frequency (\%) & $52 \%$ & $48 \%$ & \\
Hgb (g/dl) & $10.4 \pm 1.6(8-14)$ & $12.9 \pm 1.6(11-15)$ & 0.001 \\
Prohepcidin (ng/ml) & $156 \pm 14(91-245)$ & $116 \pm 19(56-128)$ & 0.001 \\
Hepcidin (ng/ml) & $71 \pm 13(62-98)$ & $59 \pm 11(31-82)$ & 0.001 \\
\end{tabular}

Hepcidin, a recently identified peptide hormone, acts as a central regulator of iron metabolism. It is regarded as a factor regulating the uptake of dietary iron and its mobilization from macrophages and hepatic stores. Hepsidin is synthesized in the liver as an 84 amino acid precursor (prohepcidin) that is subsequently processed and secreted predominantly as a 25 amino acid peptide form. ${ }^{17}$

Hepcidin is considered to be a mediator anemia of inflammation. Hepcidin production was shown to increase in invivo and invitro experimental and clinical inflammation models. The investigators demonstrated that IL-6 and lipopolysaccharide induces hepcidin mRNA expression in human hepatocytes, but TNF- $\alpha$ has no such an effect. Prolonged exposure to IL-1 (after 24 hours) also induces hepcidin mRNA expression. ${ }^{8}$ In inflammation models by turpentine, it was reported that increased hepcidin might be responsible for the development of anemia. In addition, hepcidin mRNA expression in the liver declines about threefold in anemias induced by phlebotomy and/or phenylhydrazine. ${ }^{10}$

Hepcidin also inhibits iron absorption from the intestine in mice, contributing to hypoferremia. ${ }^{13,18}$ In addition, hepcidin inhibits iron mobilization from macrophages in the reticuloendothelial system,12 and could inhibit erythroid colony formation in the bone marrow. ${ }^{19}$ Hepcidin levels in patients with active BD increased when compared to patients with inactive BD. All of these data suggest that hepcidin plays an important role in inflammatory conditions. The role of hepcidin particularly comes into prominence in anemia of inflammation. In our study, the highest serum hepcidin and prohepcidin levels were observed in BD patients. Serum transferrin level was reported to be more useful than serum iron level and total iron binding capacity in measuring the body iron status. Kahgo et al., in their study, indicated that serum soluble transferrin receptor level reflected the cellular iron shortage and could be used in differential diagnosis of ACD. ${ }^{12}$ In our study, serum transferrin levels in BD group were significantly lower than healthy controls. It was reported that hepcidin production increases in iron load $^{7.9}$ and decreases in rats fed with low iron. ${ }^{16}$ In clinical studies urinary hepcidin and serum prohepcidin levels were shown to be high in ACD..$^{9,11,12}$ Serum ferritin level increases as acute phase reactant in active BD. Hepcidin is known to be closely associated and positively correlated with ferritin. ${ }^{919}$ A positive correlation was demonstrated between serum prohepcidin and ferritin levels in chronic renal failure. ${ }^{9}$ Furthermore, Nagashima et al. reported that serum prohepcidin levels negatively correlated with ferritin levels in patients with viral hepatitis $\mathrm{C}$, while this correlation was positive in patients with viral hepatitis B and healthy controls. ${ }^{2,17}$ In our study, serum ferritin levels in BD group were significantly lower than healthy controls. Literature data point to raised C-reactive protein (CRP) concentration as a marker of systemic inflammation in BD patients. ${ }^{10}$ In our study, serum CRP levels in BD group were significantly higher than healthy controls.

Normally, most iron used for erythropoiesis is recovered from the degradation of red blood cells by reticuloendothelial macrophages. Infection, malignancy, and chronic inflammation all may result in inefficient macrophage iron release and subnormal intestinal iron absorption, contributing to the anemia of chronic disease. ${ }^{2,4}$ Classically, chronic disease anemia is associated with low serum iron and TIBC and high or normal serum ferritin levels. ${ }^{2}$ In the present BD patients, serum iron status was consistent with this classical data, however TIBC was 
not significantly different when compared to healthy controls These data suggest that hepcidin and prohepcidin are an important pathogenetic marker in pathobiology of anemia in BD patients .

\section{Conclusions}

In conclusion, our findings suggest that hepcidin and prohepcidin are strongly associated with disease activity in $\mathrm{BD}$ patients and might play a significant role in the pathobiology of chronic disease anemia associated with BD. Future studies to determine serum levels of hepcidin and prohepcidin at different time points during the clinical course of BD patients will be needed to confirm our results. Moreover, inflammatory cytokines which can induce hepcidin synthesis, such as IL-6, and serum erythropoietin levels should also be investigated concurrently to determine the exact mechanisms underlying the contribution of hepcidin and prohepcidin in the crossroad of anemia and inflammation associated with BD.

\section{REFERENCES}

1. Behçet $H$. Ueber rezivierende aphthose durch ein virus verursachte geschwuere am mund, am auge und an den genitalien. Dermatol Wochenschr 105: 11521157, 1937.

2. O'Neill TW, Rigby AS, Silman AJ, et al. Validation of the international study group criteria for Behçet's disease. $\mathrm{Br} J$ Rheumatol 33: 115-117, 1994.

3. Means RT . Advances in anemia of chronic disease. Int J Hematol 70: 7-12, 1999.

4. Weiss G, Goodnough LT. Anemia of chronic disease. N Engl J Med 352: 1011-1023, 2005.

5. Ludwiczek S, Aigner E, Theurl I, et al. Cytokine-mediated regulation of iron transport in human monocytic cells. Blood 101: 4148-4154, 2003.

6. Theurl I, Mattle V, Seifert M, et al. Dysregulated monocyte iron homeostasis and erythropoietin formation in patients with anemia of chronic disease. Blood 107: 4142-4148, 2006.

7. Means RT. Hepcidin and cytokines in anemia. Hematology 9: 357-362, 2006.

8. Nemeth E, Valore EV, Territo M, et al. Hepcidine, a putative mediator of anemia of inflammation, is a type ॥ acute-phase protein. Blood 101: 2461-2463, 2003.

9. Ganz T. Hepcidin, a key regulator of iron metabolism and mediator of anemia of inflammation. Blood 102: 783-788, 2003.
10. Nicolas G, Chauvet C, Viatte L, et al.The gene encoding the iron regulatory peptide hepcidin is regulated by anemia, hypoxia, and inflammation. J Clin Invest 110: 1037-1044, 2002.

11. Weinstein DA, Roy CN, Fleming MD, et al. Inappropriate expression of hepcidin is associated with iron refractory anemia: implications for the anemia of chronic disease. Blood 100: 3376-3381, 2002.

12. Nemeth E, Tuttle MS, Powelson J, et al. Hepcidin regulates cellular iron efflux by binding to ferroportin and inducing its internalization. Science 206: 2090-2093, 2004.

13. Rivera S, Nemeth E, Gabayan V, et al.Synthetic hepcidin causes rapid dose-dependent hypoferremia and is concentrated in ferroportin-containing organs. Blood 106: 2196-2199, 2005.

14. Evaluation of diagnostic (classification) criteria in Behçet's Disease-towards internationally agreed criteria. The International Study Group for Behçet's Disease, Br J Rheumatol 31: 299-308,1992.

15. Weiss G. Pathogenesis and treatment of anemia of chronic disease. Blood 16: 87-96, 2002.

16. Cook JD, Skikne BS. Iron deficiency: Definition and diagnosis. J Intern Med 226: 349-355, 1989.

17. Park $\mathrm{CH}$, Valore $\mathrm{EV}$, Waring AJ, et al. Hepcidin, a urinary antimicrobial peptide synthesized in the liver. J Biol Chem 276: 7806-7810, 2001.

18. Mena NP, Esparza A, Tapia V, et al. Hepcidin inhibits apical iron uptake in intestinal cells. Am J Physiol Gastrointest Liver Physiol 294: 192-198, 2008.

19. Means RT. Recent developments in the anemia of chronic disease. Curr Hematol Rep 2: 116-121, 2003.

\section{Correspondence}

Dr. Mehmet DAĞLI

S.Ü. Selçuklu Tıp Fakültesi Hematoloji Bilim Dalı

42170 Selçuklu, KONYA / TURKEY

Tel: (+90.332) $2415000 / 44654$

Fax: (+90.332) 2416063

e-mail: drmdagli@hotmail.com 